\title{
The improvement of functional food in yogurt enriched with purple sweet potato (Ipomea batatas var. Ayamurasaki)
}

\author{
F. Afiati*, G. Priadi and F. Setiyoningrum \\ Research Center for Biotechnology, Indonesian Institute of Science (LIPI), \\ Jl. Raya Bogor Km.46 Cibinong 16911 - Indonesia \\ *Corresponding E-mail: afiati.biotek@gmail.com
}

Received November 15, 2017; Accepted February 12, 2018

\begin{abstract}
ABSTRAK
Penelitian ini dilakukan untuk menguji penggunaan ubi jalar ungu (Ipomoea batatas var Ayamurasaki) dalam meningkatkan nilai fungsional yogurt. Perlakuan penelitian menggunakan 2 faktor. Faktor pertama (i) adalah konsentrasi susu skim, dengan taraf $0 \%, 3 \%$ dan $6 \%$, faktor kedua (ii) adalah konsentrasi ubi jalar ungu, dengan taraf $0 \%, 2 \%$ dan 4\%. Parameter yang diamati adalah viabilitas bakteri asam laktat (BAL), $\mathrm{pH}$, kadar air, protein, lemak, karbohidrat, abu dan serat kasar serta organoleptik. Hasil penelitian menunjukkan bahwa tidak ada interaksi antara konsentrasi susu skim dan ubi jalar ungu terhadap total BAL, kadar air dan serat kasar. Namun, interaksi terjadi pada kadar lemak, protein, karbohidrat dan abu. Hasil uji organoleptik yang diperkaya dengan $2 \%$ ubi jalar ungu tanpa penambahan skim lebih disukai oleh panelis dengan tingkat kesukaan 3,65.
\end{abstract}

Kata kunci: yogurt, ubi jalar ungu, fisikokimia, mikrobiologi, organoleptik

\begin{abstract}
The research was conducted to examine the use of purple sweet potato (Ipomoea batatas var. Ayamurasaki) to improve functional food of yogurt. This experiment has 2 factors of treatments. The first factor (i) was concentration of skim milk, i.e. $0 \%, 3 \%$ and $6 \%$; the second factor (ii) was concentration of purple sweet potato, i.e. $0 \%, 2 \%$ and $4 \%$ of purple sweet potato. The parameters observed were viability of lactic acid bacteria (LAB), $\mathrm{pH}$, moisture content, protein, fat, carbohydrate, ash and crude fiber and organoleptic. The results showed that there was no interaction between the concentration of skim-milk and the purple sweet potato on total LAB, moisture content and crude fiber. However, the interaction occurred on the levels of fat, protein, carbohydrate and ash. The organoleptic test results that yogurt enriched by $2 \%$ purple sweet potato without addition of skim was more preferable by panelist with a value of 3.65 .

Keywords: yogurt, purple sweet potato, physicochemical, microbiology, organoleptic
\end{abstract}

\section{INTRODUCTION}

According to ISO 2981 (BSN, 2009) yogurt is the product obtained from the fermentation of milk and or reconstituted milk by using Lactobacillus bulgaricus (LB) bacteria and Streptococcus thermophilus (ST) and or other suitable lactic acid bacteria (LAB), with or without the addition of the others foodstuffs and permitted food additives. Fresh milk as the basic ingredient of yogurt has lower nutritional value than yogurt, because fermented milk can increase the total solids, so that the content of other nutrients also increase (Wahyudi and Samsundari, 
2008). Both yogurt-forming bacteria cannot live in the digestive tract where the acidity is very high, so it needs the addition of LAB probiotics, such as Lactobacillus acidophilus, Lactobacillus casei and Bifidobacterium which can live and perform metabolism in the intestine.

Probiotics are living organisms capable of providing beneficial effects on theirs host health if consumed in sufficient quantities (FAO/WHO, 2001) by improving intestinal microflora balance when moving inward into the gastrointestinal tract (Weichselbaum, 2009). A good balance in the intestinal microflora ecosystem can be benefit to the health of the body and be affected by the consumption of probiotics on daily basis (Lisal, 2005). To stimulate its growth, probiotic bacteria can be combined with prebiotic sources.

Prebiotics are materials, included indigestible carbohydrate that induced enhancing of saccharolytic fermentation and production of short chain fatty acid (SCFA) (Roberfroid et al., 2010; Cani and Delzenne, 2009). FAO (2007) define a prebiotic as non-viable food component that confers a health benefit on the host associated with modulation of the microbiota (FAO, 2007). Since prebiotics are indigestible carbohydrates, all prebiotics are dietary fibers. Dietary fibers are indigestible carbohydrates of plants, which have physiological effects in human. Dietary fibers were divided into soluble or insoluble. The solubility confers dietary distinct functionalities to dietary fibers, some of which having different health benefits for the hosts metabolism (Slavin, 2013). Moreover, prebiotics can confer a health benefit on the host associated with microbiota on gastrointestinal system (Pineiro et al., 2008). Prebiotic sources of food such as soybeans, taro, "garut" bulbs, sweet potato, and breadfruit. Prebiotics should be existed in the food consumed and contain lots of oligosaccharides. According to Muchtadi (2005), oligosaccharides had low molecular weight of carbohydrates, consisted of three to ten simple sugar (monosaccharide) groups, such as raffinose, stakiosa and verbaskosa, and contained in plants such as nuts and some tubers. Oligosaccharides cannot be digested because human's intestines do not have the appropriate enzymes to digest them so they cannot be absorbed. Furthermore, oligosaccharides will be fermented, used as a source of energy by bacteria in the digestive tract. As a result, they can stimulate the growth of probiotic bacteria and suppress pathogenic bacteria in the digestive tract.
Purple sweet potato or Ipomoea batatas L. Poir type has a sufficiently dark purple color that attracts a lot of attention (Hardoko et al., 2010). Obviously, sweet potato has rich of starch that can be used as a carbon source in fermentation of probiotic bacteria (Dong et al., 2017). Dong et al. (2017) mentioned that sweet potatoes have approximately $46-55 \mathrm{~g} / 100 \mathrm{~g}$ (db, dry base) of starch. Other functional value of purple sweet potato is as antioxidant source. Purple sweet potato is a source of vitamin $\mathrm{C}$ and beta-carotene (Siregar et al., 2014). The purple sweet potato also has flavonoid components, an anthocyanin natural dye (Husna et al., 2013; Ahmed et al., 2010) which its content ranges around 14.68$210 \mathrm{mg} / 100 \mathrm{~g}$ of material (Jaya, 2010). The research of Wang et al. (2017) has revealed that anthocyanin of purple sweet potato has hepatoprotective activity in mice.

Purple sweet potato contained relatively high of amylose $29.91 \%$ (db, dry base), which makes it a potential resource of resistant starch production (Zheng et al., 2016). Resistant starch has been proven as a functional prebiotic (Zhang et al., 2013). Resistant starch has been revealed having health benefit such as reducing the glycemic response (Bodinham et al., 2014); lowering blood cholesterol (Nichenametla et al., 2014), and increasing the production of short chain fatty acid (SCFA) in the large intestine (Gibson et al., 2004).

In addition to the secondary function (giving sensory satisfaction in the aroma, taste, color, and texture), food also has tertiary function namely the capacity of food to improve the modulation of the body's physiological system (immunity, endocrine, nerves, circulation and digestion) in addition to the nutritional benefits that already exist. The food component that has this particular function is better known as functional food (Suhartini, 2009). Yogurt is very influential for the entire human health as a functional food i.e. probiotics drinks (Wahyudi and Samsundari, 2008). A prebiotic source also can be added into yogurt to improve nutritional value. Some prebiotic source was used to make fermented milk (yogurt) i.e. rice bran (Demirci et al., 2017) organic green banana flour (Batista et al., 2017), and inulin (Ramchandran et al., 2010; Miremadi et al., 2017). This research aims was to evaluate the effect of purple sweet potato flour addition as a source of prebiotic on microbiological, physicochemical, and sensory of yogurt. 


\section{MATERIALS AND METHODS}

The materials used to make purple sweet potato yogurt were fresh milk, skim milk, purple sweet potato flour, cultured-yogurt, MRSA (de Man ROGOSA Sugar Agar, Merck), $\mathrm{NaCl}$ (Merck), phenolphthalein, boric acid, $0.1 \mathrm{~N} \mathrm{HCl}$, $30 \% \mathrm{NaOH}$ (Merck), $\mathrm{H}_{2} \mathrm{SO}_{4}$ (Merck, 98\%), filter paper, n-hexane (Merck), and ethanol (Merck, $95 \%)$.

The equipments used were a stainless steel pan, an electric heater, analytical scale, a petri dish, micropipette, laminar flow, colony counter, autoclaves, incubators, $\mathrm{pH}$ meter, oven, furnace, soxhlet apparatus, kjeldahl apparatus, porcelain bowls and other glasswares.

\section{Purple sweet potato-yogurt formulations}

Before being used in the manufacture of yogurt, yogurt starter, containing Lactobacillus bulgaricus and Streptococcus thermophillus, was adapted first by as much as 1 liter of fresh milk sterilized at a temperature of $110^{\circ} \mathrm{C}$ for 10 minutes using an autoclave. After it was cooled down, $15 \%$ of yogurt culture was inoculated in aseptic, then incubated at $30^{\circ} \mathrm{C}$ for 24 hours.

The final step of making prebiotic yogurt was by heating fresh milk to a temperature of $50^{\circ} \mathrm{C}$, then put skim milk and purple sweet potato flour with a particular concentration according to the treatment of yogurt. Then re-heat the milk, stirred in a temperature of $85^{\circ} \mathrm{C}$ and held for 10 minutes. Then inoculate $1.5 \%$ of work culture in yogurt, incubated at $30^{\circ} \mathrm{C}$ for 20 hours. The factors tested in purple sweet potato yogurt formulation were the purple sweet potato of $0 \%, 2 \%$ and $4 \%$ concentration and skim milk of $0 \%, 3 \%$ and $6 \%$ concentration.

\section{Analysis of Lactic Acid Bacteria Viability}

One $\mathrm{mL}$ samples of yogurt incorporated in the diluent solution $(0.85 \%$ of $\mathrm{NaCl}$ as much as 9 $\mathrm{mL}$ ), then homogenized until homogeneous, thus obtained dilutions of $10^{-1}$. The dilution process was carried out to $10^{-9}$ level. Fertilization using MRSA media is done from dilutions $10^{-5}$ to $10^{-9}$ by using poured gel (pour plate) method, Duplo. The counting of colonies grown performed after incubation process at $30^{\circ} \mathrm{C}$ for 48 hours.

\section{Proximate Analysis}

The analysis of water, protein, fat, ash and fiber contents was done using the $\mathrm{AOAC}$ (AOAC,
2005) method. Carbohidrate was measured by difference method.

\section{Organoleptic Test}

The method used for organoleptic test was the hedonic rating test. Organoleptic test was conducted by 70 of untrained panelists, $20-45$ years old. The tested parameters were the color, aroma, texture, flavor, and overall aspect. The test scales used were $1=$ extremely unfavourable, $2=$ unfavourable, $3=$ neutral, $4=$ favourable, $5=$ extremely favourable.

\section{Data Analysis}

This research uses factorial design in group design. The factors tested were (1) concentration of purple sweet potato of $0 \%, 2 \%, 4 \%$ and (2) concentration of skim milk of $0 \%, 3 \%$ and $6 \%$. Every treatment was done twice. Data were analyzed by analysis of variance (ANOVA) at $5 \%$ level. If there was significant difference then tested with Duncan's Multiple Range Test.

\section{RESULTS AND DISCUSSION}

The nutritional value of purple sweet potato flour were moisture, fat, protein, carbohydrate, crude fiber and ash content. Nutritional composition and bio-functions of sweet potato were affected by the varieties, plant parts, extraction time and solvents, postharvest storage, and processing (Wang et al., 2016). The main nutritional content of purple sweet potato flour is carbohydrate. This is as described by Siregar et al. (2014) that purple sweet potato is one of the food sources of carbohydrates that can be used as a raw material in probiotic drinks diversification. Carbohydrates contents (86.28\%), which are used as a source of prebiotic, almost equals to the results of Hardoko's study namely $86.7 \%$ (Hardoko et al., 2010). The starch content value of purple sweet potato $(5.14 \%)$ was lower than that of Hardoko et al. (2010), which is 7\%, but still in the standard range of SNI No. 01-37512006, where the maximum moisture content is $14.5 \%$. Based on crude fiber content, the purple sweet potato flour has potential as functional food ingredients or food health, especially it dietary fiber to the activity of antioxidant (Hardoko et al., 2010). Furthermore, dietary fiber has known having benefit to stimulates selectively microbe (probiotics) in the intestine (Bultosa, 2016) and providing beneficial health effects (Rassmunsen et al., 2017) such as producing SCFA (Roberfroid 
et al., 2010), and preventing inflammatory bowel disease (Rassmunsen et al., 2017). The nutritional content of purple sweet potato flour is presented in Table 1.

The protein content of purple sweet potato $(4.65 \%)$ was higher than those of Ambarsari et al. (2009) and Hardoko et al. (2010) studies those were $2.79 \% / 100 \mathrm{~g}$ and $1.69 \%$, respectively. Ambarsari et al. (2009) stated that the purple sweet potato flour was made to substitute wheat flour, eventhough the purple sweet potato flour contained low in protein. The protein content of purple sweet potato in this research was higher than those in Dong et al. (2017) research which was $1.61-3.93 \%$.

There was not any difference addition of purple sweet potato flour and/or skim milk in the viability of lactic acid bacteria $(p>0.05)$. The survival of yogurt bacteria, $S$. thermophillus spp. and L. bulgaricus delbueckii, in the prebiotic yogurt ranges from 8.55 to $9.04 \log \mathrm{cfu} / \mathrm{mL}$ (Table 2 ). The amount of lactic acid bacteria in yogurt is in line with SNI yogurt, which requires a minimum amount of LAB as many as $10^{7}$ colonies LAB/gram (BSN, 2009). The same phenomenon was reported by Cruz et acl. (2013) that the number of LAB in the yogurt which was oligofructose enriched, ranged from 8.21 to 9.56 $\log \mathrm{cfu} / \mathrm{mL}$. Moschopoulou (2018) reported that no significant differences were observed among the bacterial counts of four yogurts added by various level of milk. The viability and value of $\mathrm{pH}$ of purple sweet potato yogurt are presented in Table 2 .

The treatments with/without the purple sweet potato flour and skim milk did not significantly affect the $\mathrm{pH}$ of yogurt $(\mathrm{p}>0.05)$, ranging between 3.73 to 4.16 (Table 2). Setiyoningrum et al. (2016) revealed the same phenomenon that $\mathrm{pH}$ of yogurt did not interfere with the addition of skim milk or red bean powder. However, Sayuti et al. (2013) stated that the addition of purple sweet potato extract (0-15\%) and skim milk (0-7\%) has a very significant effect on yogurt $\mathrm{pH}$ ranging from 3.623 to 4.28. Strain of lactic acid bacteria in yogurt, duration, incubation temperature, and ingredients which were added to the yogurt affected the $\mathrm{pH}$ of yogurt. Accumulation of lactic acid produced by LAB induced the decrease of $\mathrm{pH}$ in yogurt (Yildz, 2010).

Oligosaccharide in sweet potato is carbohydrates that are beneficial to the growth of probiotic bacteria so that the presence of the oligosaccharide can assist the production lactic
Table 1. Nutritional Content of Purple Sweet Potato Flour

\begin{tabular}{lc}
\hline \multicolumn{1}{r}{ Parameter } & Amount (\%) \\
\hline Water & 5.14 \\
Protein & 4.65 \\
Fat & 0.01 \\
Carbohydrate & 86.28 \\
Ash & 3.34 \\
Coarse fiber & 0.39 \\
\hline
\end{tabular}

Table 2. LAB Vablity and $\mathrm{pH}$ Value of Yogurt

\begin{tabular}{ccc}
\hline $\begin{array}{c}\text { Treatment } \\
\text { (skim milk: } \\
\text { prebiotics) }\end{array}$ & $\begin{array}{c}\text { LAB Viability } \\
\text { (log 10) }\end{array}$ & $\mathrm{pH}$ \\
\hline 0: 0 & 8.65 & 3.86 \\
0: 2 & 8.74 & 3.90 \\
0: 4 & 8.99 & 3.73 \\
3: 0 & 8.90 & 3.96 \\
3: 2 & 8.71 & 4.08 \\
3: 4 & 8.99 & 3.99 \\
6: 0 & 9.04 & 4.03 \\
6: 2 & 8.55 & 4.07 \\
6: 4 & 8.94 & 3.96 \\
\hline
\end{tabular}

acid and $\mathrm{pH}$ to be more effective (Utami et al., 2010). In line with the opinion of Siregar et al. (2014), when there is more sugar component and bigger simple extracted molecules, the more energy can be used for the growth of microorganisms, the more of lactic acid bacteria population, the more LAB formed. The higher acidity did not interfere in the viability of LAB in prebiotic yogurt enriched with sweet potato (Januario et al., 2017).

Figure 1 showed the contour plot of the water content, protein, fat, carbohydrate, ash content and crude fiber yogurt response caused by a combination of skim and purple sweet potato. Contour plot for water content has a regular pattern, the increase of skim and purple sweet potato concentration made lower water content in 

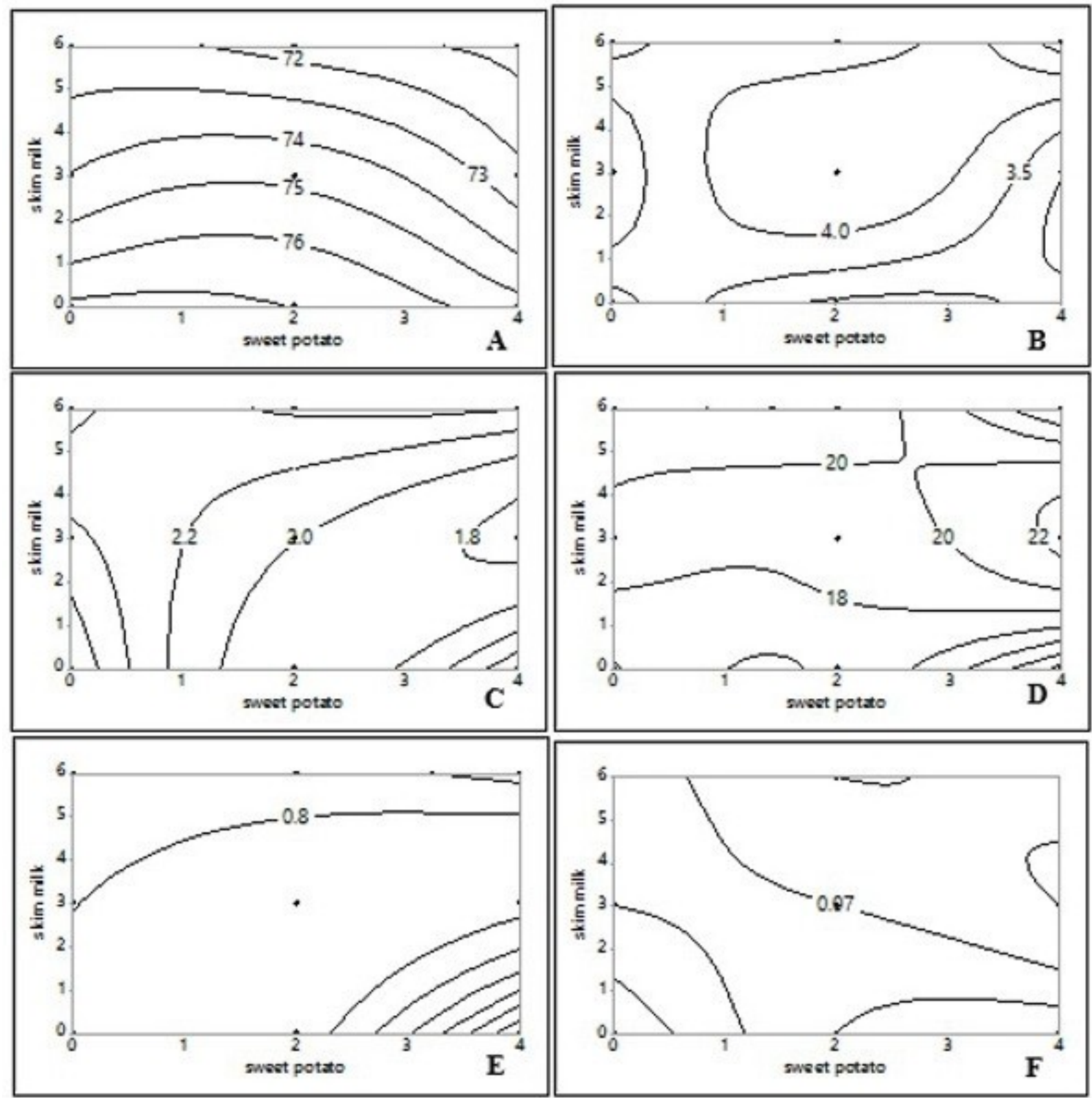

Figure 1. Contour Plot of Skim Milk and Purple Sweet Potato on (A) Water content, (B) Protein, (C) Fat, (D) Carbohydrate, (E) Ash content and (F) Crude fiber

yogurt. On the other response, there did not have regular pattern.

The addition of purple sweet potato and skim milk gave significant effect on the water content of yogurt $(\mathrm{p}<0,05)$. The increase concentration of purple sweet potato flour and/or skim milk induce decreasing of moisture content from $77.22 \%$ to $70.74 \%$ in the yogurt. The lowest moisture content was shown by yogurt which added by $6 \%$ of skimmed milk and $4 \%$ of purple sweet potato.

The content of protein in the yogurt ranged from 2.90 to $5.28 \%$. The highest concentration of the purple sweet potato flour (2 to 4 ) or skim milk (0 to 6) gave effect to the protein content of the yogurt. The addition of $6 \%$ skimmed milk and $4 \%$ purple sweet potato flour showed the highest protein content $(5.28 \%)$. Addition of skim milk might increase protein content in the yogurt. Skim milk contains approximately $34.5 \%$ of protein (Ryder et al., 2018). Furthermore, the protein in purple sweet potato flour and skim milk amounted to $4.65 \%$, while the protein in the milk was $36.2 \%$ 
a. color

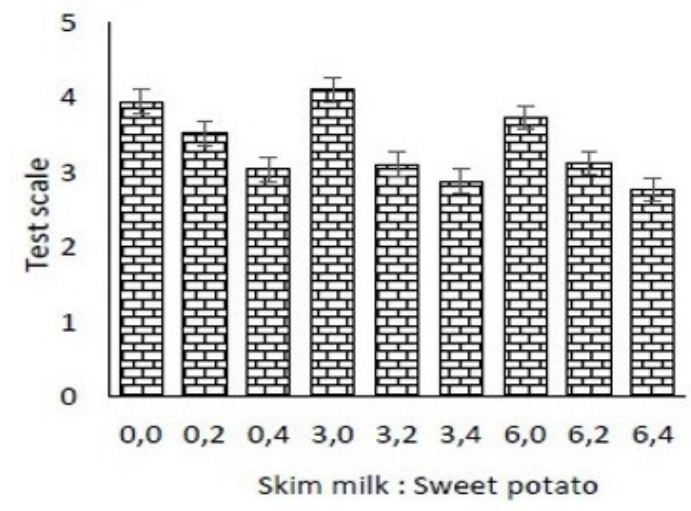

c. flavor

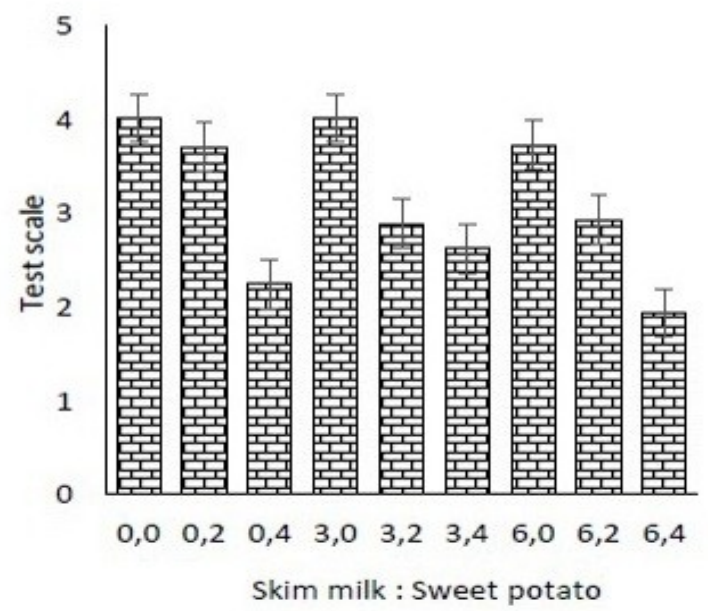

e. over all b. Taste

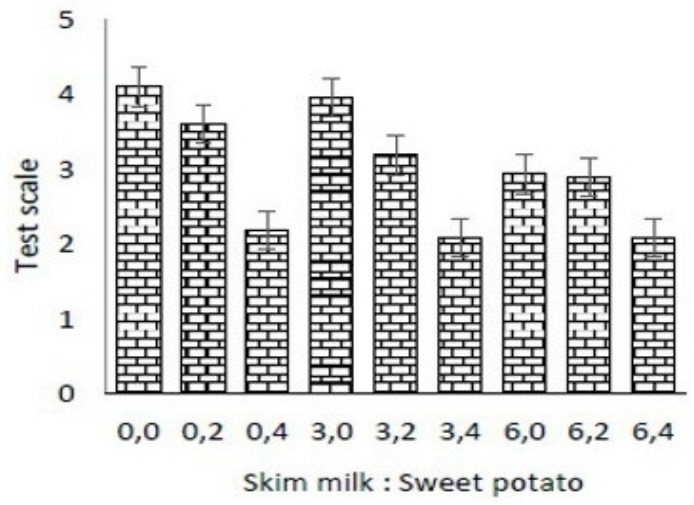

d. appearance

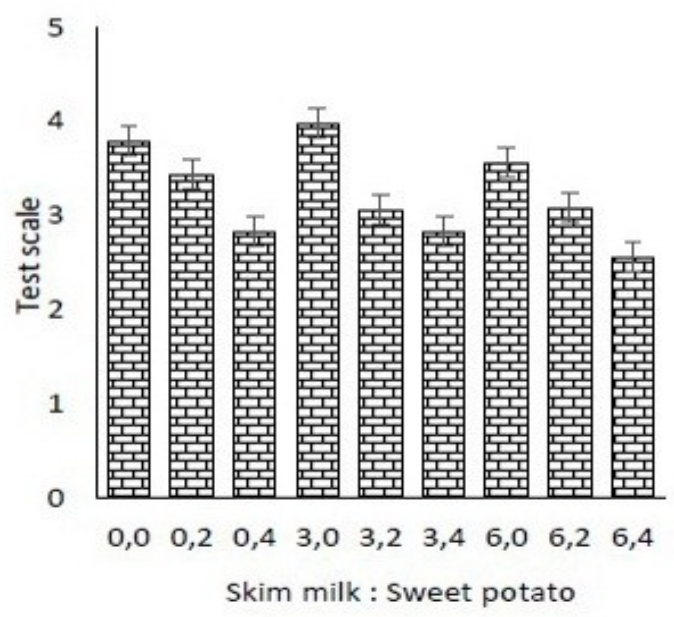

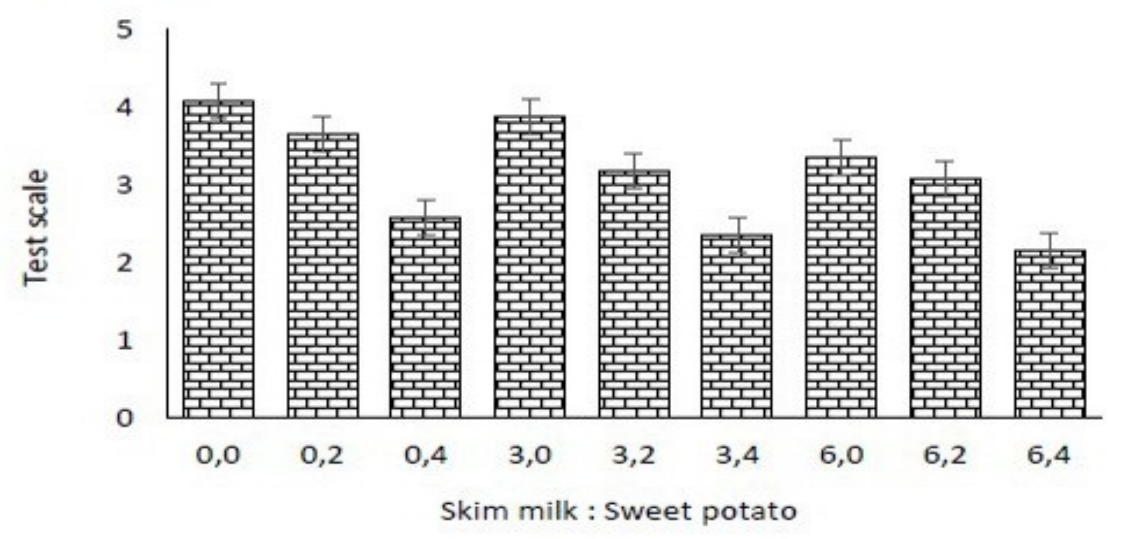

Figure 2. Sensory Evaluation of Yogurt (color, taste, flavor, appearance, overall)

(FAO, 2013).

The lowest content of low fat in yogurt $(1.76 \%)$ was produced from the addition of $3 \%$ purple sweet potato flour and $4 \%$ skimmed milk, the addition of $4 \%$ purple sweet potato flour significantly affect $(p<0.05)$ the fat content. Purple sweet potato flour and skim milk contains low fat concentrations, so that only a very small 
Table 3. Nutritional Content of Yogurt

\begin{tabular}{ccccccc}
\hline $\begin{array}{c}\text { Treatment } \\
\text { (skim milk: } \\
\text { prebiotics) }\end{array}$ & $\begin{array}{c}\text { Water } \\
(\%)\end{array}$ & $\begin{array}{c}\text { Protein } \\
(\%)\end{array}$ & $\begin{array}{c}\text { Fat } \\
(\%)\end{array}$ & $\begin{array}{c}\text { Carbohydrate } \\
(\%)\end{array}$ & $\begin{array}{c}\text { Ash } \\
(\%)\end{array}$ & $\begin{array}{c}\text { Crude fiber } \\
(\%)\end{array}$ \\
\hline $0: 0$ & 77.22 & 4.28 & 2.80 & 15.78 & 0.66 & 0.05 \\
$0: 2$ & 76.96 & 2.90 & 1.88 & 17.64 & 0.68 & 0.08 \\
$0: 4$ & 75.36 & 3.27 & 2.59 & 9.43 & 1.99 & 0.09 \\
$3: 0$ & 74.06 & 3.14 & 2.45 & 19.15 & 0.81 & 0.07 \\
$3: 2$ & 74.75 & 4.41 & 2.01 & 18.68 & 0.65 & 0.07 \\
$3: 4$ & 72.36 & 3.05 & 1.76 & 22.53 & 0.74 & 0.06 \\
$6: 0$ & 72.63 & 4.28 & 2.15 & 20.77 & 0.94 & 0.08 \\
$6: 2$ & 71.58 & 3.64 & 2.43 & 21.32 & 0.93 & 0.06 \\
$6: 4$ & 70.74 & 5.28 & 2.41 & 13.56 & 1.08 & 0.07 \\
\hline
\end{tabular}

portion of fat content contributes in yogurt formula. The fat content of skim milk is $1.5 \%$ (FAO, 2013). Lactic acid bacteria have lipolitic enzymes that can digest fat thereby causing an increase in the fat content of the product (Gardiner et al., 2000).

The combination of purple sweet potato flour and skim milk yogurt gave effect on carbohydrate content $(p<0.05)$. Increasing concentrations of purple sweet potato flour and skim milk have also increased the carbohydrate content. The highest carbohydrate content was in yogurt containing 3\% skimmed milk and $4 \%$ purple sweet potato flour (Table 3). The carbohydrate content of purple sweet potato flour was $86.28 \%$ (Table 1) and thus contributes to the carbohydrate content of yogurt. The level of concentration of skim milk affected ash yogurt content $(p<0.05)$. The addition of $4 \%$ purple sweet potato flour significantly $(\mathrm{p}<0.05)$ increased the levels of ash, especially in the yogurt that did not receive the addition of skim milk (Table 3). The ash content of purple sweet potato was $3.34 \%$ (Table 1), increasing concentration of purple sweet potato flour that added in yogurt was expected increasing of ash content.

Table 3 shows that the crude fiber content of yogurt was from 0.05 to $0.09 \%$. The concentration levels of purple sweet potato flour and/or skim milk has no effect on the crude fiber content of yogurt ( $\mathrm{p}>0.05$ ).

The sensory diagram in Figure 2 shows the highest score of overall parameter resulting from yogurt without purple sweet potato flour and skim milk (plain yogurt). The best formulations of prebiotic yogurt was yogurt which was added by $3 \%$ of skimmed milk without the addition of purple sweet potato flour. That score was quite similar to the control yogurt which was 4, particularly for the taste, color, smell and appearance properties. Based on these results, it showed that the increase of purple sweet potato flour caused by fiber type or prebiotic source affected the sensory acceptance. Ares et al. (2009) reported negative results of organoleptic tests on milk pudding which was added with a new type of fiber. Furthermore, Cruz et al. (2013) emphasized that it was important to conduct a sensory test on ordinary consumers of the product in order to find better formulation. The important factor to gain consumer acceptance is that the product must show the same features as the original product.

\section{CONCLUSION}

The addition of purple sweet potato flour and skim milk in yogurt has contributed to the physicochemical and sensory properties of the yogurt. The increase of purple sweet potato flour or skim milk in yogurt resulted in lower carbohydrate content. In other words, high concentrations of purple sweet potato and skim milk are responsible in the decrease of water content. Viability of BAL and crude fiber content 
was not affected by the increase and decrease of purple sweet potato flour or skim milk concentration. Based on the sensory test results, the addition of $3 \%$ of skim milk can be the best recommended formula of yogurt enriched with purple sweet potato flour.

\section{ACKNOWLEDGMENTS}

Thank you for The Competitive Program at Techno park Tasikmalaya 2015 and Surya University for the funding and assistance in the completion of this study.

\section{REFERENCES}

Ahmed, M., M.S. Akter, J.C. Lee and J.B. Eun. 2010. Encapsulation by spray drying of bioactive components, physicochemical and morphological properties from purple sweet potato. LWT-Food Sci. Tech. 43:1307-1312

Ambarsari I., Sarjana and A. Choliq. 2009. Rekomendasi dalam penetapan standar mutu tepung ubi jalar. J. Standarisasi. 11(3):212-219

AOAC. 2005. Official method of analysis of the AOAC. $14^{\text {th }}$ ed. Virginia:AOAC, Inc.

Ares, G., A. Gimenez and A. Gámbaro. 2009. Consumer perceived healthiness and willingness to try functional milk desserts. Influence of ingredient, ingredient name and health claim. Food Qual. Prefer. 20:5056

Badan Standardisasi Nasional. 2009. Yogurt. SNI 2981. Jakarta

Batista, A.L.D., R. Silva, L.P. Cappato, M.V.S. Ferreira, K.O. Nascimento,M. Schmiele, M. Esmerino, E.A. Balthazar, C.F. Silva, H.L.A. Moraes, J. Pimentel, T.C. Freitas, M.Q. Raices, R.S.L. Silva and A.G. Cruz. 2017. Developing a synbiotic fermented milk using probiotic bacteria and organic green banana flour. J. Func. Foods. 38:242250

Bodinham, C.L., L. Smith, E.L. Thomas, J.D Bell, J.R. Swann, A. Costabile, D.R. Jones, A.M. Umpleby and M.D. Robertson. 2014. Efficacy of increased resistant starch consumption in human type 2 diabetes. Endocr. Connect. 3:75-84

Bultosa, G. 2016. Functional Foods: Dietary Fibers, Prebiotics, Probiotics, and Synbiotics. Ref. Modl. Food Sci. 2:11-16

Cani, P.D and N.M. Delzenne. 2009. The role of the gut microbiota in energy metabolism and metabolic disease. Curr. Pharm.:1546 1558

Cruz, AG., R.N Cavalcanti, L.M.R. Guerreiro, A.S. Sant'Ana, L.C. Nogueira, C.A.F . Oliveira, R. Deliza, R.L. Cunha, J.A.F. Faria and H.M.A. Bolini. 2013. J. Food Eng. 114:323-330

Demirci, T., K. Aktas, Sőzeri, H. I. Öztūrk and N. Akin. 2017. Rice bran improve probiotic viability in yoghurt and provide added antioxidative benefits. J. Func. Food. 36:396-403

Dong, J., M. Tai-hua and S. Hong-nan. 2017. Sweet potato and potato residual flours as potential nutritional and healthy food material. J. Integr. Agric. 16(11):2632-2645

FAO. 2007. FAO Technical Meeting on Prebiotics: Food Quality and Standards Service (AGNS). FAO Tech. Meet. Rep. FAO Rome, Italy, 15-16 September 2007

FAO. 2013. Milk and dairy products in human nutrition. Edited by: E. Muehlhoff A. Bennett, D. McMahon. FAO Roma. P.67-99

FAO/WHO. 2001. Joint FAO/WHO Expert Consultation on Evaluation of health and nutritional properties of probiotics in food including powder milk with live lactic acid bacteria. Amerian Córdoba Park Hotel, Córdoba, Argentina

Gardiner, G.E., E.O. O’Sullivan, J. Kelly, M.A.E. Auty, G.F. Fitzgerald, J.K. Collins, R.P. Ross and C. Stanton. 2000. Comparative Survival Rates of Human-Derived Probiotic Lactobacillus paracasei and L. salivarius Strains during Heat Treatment and Spray Drying. App. Environ. Microb. 66(6):26052612

Gibson, G.R., H.M. Probert, J. van Loo, R.A. Rastall and M. Roberfroid. 2004. Dietary modulation of the human colonic microbiota: Updating the concept of the prebiotics. Nutr. Res. Rev. 17:259-275

Hardoko, L,. Hendarto and T.M. Siregar. 2010. Pemanfaatan ubi jalar ungu (Ipomeoea batatas L. Poir) sebagai pengganti sebagian tepung terigu dan sumber antioksidan pada roti tawar. J. Teknol. Ind. Pang. 21(1):25-32

Husna, N.E., M. Novita and S. Rohaya. 2013. Kandungan antosianin dan aktivitas antioksidan ubi jalar ungu segar dan produk olahannya. Agritech. 33(3):296-302

Januario, J.G.B., I.C.F. da Silva, A.S. de Oliveira, J.F. Oliveira, J.N. Dionisio, S.J. Klososki 
and T.C. Pimentel. 2017. Probiotic yoghurt flavored with organic beet with carrot, cassava sweet potato or corn juice : Physicichemical and texture evaluation, probiotic viability and acceptance. Int. Food Resch. J. 24(1):359-366

Lisal JS. 2005. Konsep probiotik dan Prebiotik untuk modulasi microbiota usus besar. Med. Nus:256-262

Miremadi, F., F. Sherkat and L. Stojanovska. 2017. Health promoting effect of synbiotic yogurt containing pomegranate polyphenols: Scientific evidence. Maturitas:100: 140

Moschopoulou E, L. Sakkas L, E. Zoidou, G. Theodorou, E. Sgouridou, C. Kalathaki, A. Liarakou, A. Chatzigeorgiou, I. Politis, G. Moatsou. 2018. Effect of milk kind and storage on the biochemical, textural and biofunctional characteristics of set-type yogurt. Int. Dairy J. 77:47-55

Muchtadi, D. 2005. Oligosakarida yang Menyehatkan. Department of Food Science and Technology IPB. Bogor

Nichenametla, S.N., L.A. Weidauer, H.E. Wey, T.M. Beare, B.L. Specker and M. Dey. 2014. Resistant starch type 4-enriched diet lowered blood cholesterols and improved body composition in a double blind controlled cross-over intervention. Mol. Nutr. Food Res. 58:1365-1369

Pineiro, M., Asp, N.-G., Reid, G., Macfarlane, S., Morelli, L., Brunser, O., Tuohy, K., 2008. FAO Technical meeting on prebiotics. J. Clin. Gastroenterol. 42(Suppl. 3):S156S159

Ramchandran, L. and N.P. Shah. 2010. Characterization of functional, biochemical and textural properties of synbiotic low-fat yogurts during refrigerated storage. Food Sci. and Tech. 43(5):819-827

Rasmussen H.E.R.D.N and B.R. Hamaker. 2017. Prebiotics and inflammatory bowel disease. Gastroenterology Clinics of North America. 46:783-795

Roberfroid, M., G.R. Gibson, L. Hoyles, A.L. McCartney, R. Rastall, I. Rowland, D. Wolvers, B.H. Watzl, B. Szajewska, F. Stahl, F. Guarner, K. Respondek, V. Whelan, M.J. Coxam, L. Davicco, Y. Leotoing, N.M. Wittrant, P.D. Delzenne, A.M. Cani, A. Neyrinck and Meheust. 2010. Prebiotic effects: metabolic and health benefits. Br. J. Nutr. 104(2):S1-63
Ryder, K., M. A. Ali, J. Billakanti and A. Carne. 2018. Fundamental characterisation of caseins harvested by dissolved air flotation from dairy wastewater and comparison with skim milk powder. Int. Dairy J. 78:112-121

Sayuti, I., S. Wulandari and D.K. Sari. 2013. Efektifitas penambahan ekstrak ubi jalar ungu (Ipomoea batatas var. Ayamurasaki) dan susu skim terhadap kadar asam laktat dan $\mathrm{pH}$ yoghurt jagung manis (Zea mays L. saccharata) dengan menggunakan inoculum Lactobacillus acidophilus dan Bifidobacterium sp. Jur. Biogenesis 9(2):2127

Setiyoningrum F, G. Priadi and F. Afiati. 2016. Developing a prebiotic yogurt enriched by red bean powder: microbiological, physicochemical and sensory aspect. Proc. Int. Symp. Appl. Chem. (ISAC). doi: 10.1063/1.4973167. http://dx.doi.org/10.1063/1.4973167

Siregar, W.E., S.Ginting and L.N. Limbong. 2014. Pengaruh perbandingan ubi jalar ungu dengan air dan konsentrasi starter terhadap mutu minuman probiotik sari ubi jalar ungu. J. Rekayasa Pangan Pertanian. 2(3):22-29

Slavin J. 2013. Fiber and prebiotics: mechanisms and health benefits. Nutrients (5):14171435

Suhartini. 2009. Prospek ubijalar sebagai bahan baku minuman probiotik. Iptek. Tan. Pang. 4(2): 169-180

Utami, R., M.A.M. Andriani and A.P. Zoraya. 2010. Kinetika fermentasi yoghurt yang diperkaya ubi jalar (Ipomoea batatas). J. Caraka. Rev. 25(1):51-55

Wahyudi, A and S. Samsundari, 2008. Bugar dengan susu fermentasi. UMM-Press, Malang

Wang L., Y. Zhao, Q. Zhou, C. Liluo, A. PingDeng, Z. ChengZhang and J. LiangZhang. 2017. Characterization and hepatoprotect activity of antocyanins from purple sweet potato (Ipoemea batatas L. cultivar Eshu No. 8). J. Food Drug Anal. 25:607-618

Wang S., S. Nie and F. Zhu. 2016. Chemical constituents and health effects of sweet potato. Food Res. Int. 89(1):90-116

Weichselbaum, E. 2009. Probiotics and health: a review of the evidence. Nutrition Bulletin. 34:340-373

Yildiz, F. 2010. Development and Manufacture of 
Yogurt and Other Functional Dairy Products. Taylor and Francis Group. United State

Zhang, Y., Y. Wang, B. Zheng, X. Lu, and W. Zhuang. 2013. The in vitro effects of retrograded starch (resistant starch type 3) from lotus seed starch on the proliferation of Bifidobacterium adolescentis. Food Funct. 4:1609-1616

Zheng, Y., Q. Wang, B. Li, L. Lin, R. Tundis, M.R. Loizzo, B. Zheng and J. Xiao. 2016. Characterization and Prebiotic Effect of the Resistant Starch from Purple Sweet Potato. Molecules. 21:932 